\section{Sedimentary microrhythms}

WITH regard to the interesting article by House $^{1}$ in which sedimentary microrhythms from marine Jurassic strata of southern England were investigated, the following may be of additional interest.

House assigned 60 ammonite zones to the Jurassic period, of which two were referred to the non-marine Lulworth Beds (Purbeck Beds). In the Purbeck Beds of Dorset and the Weald 39 cycles have been identified among the ostracod faunas which Anderson and Bazley ${ }^{2}$ have termed faunicycles. One faunicycle comprises an alternation of two ostracod assemblages: (1) species identified as tolerant of relatively saline waters (S-phase); (2) species tolerant of brackish to almost freshwater conditions (C-phase). The ostracod genus Cypridea dominates the C-phase of the faunicycles. The number of ammonite zones (among other biostratigraphical tools) allocated to the Lulworth Beds (without ammonites) will ultimately depend on the positioning of the internationally agreed base of the Cretaceous period. In southern England the Cinder Bed Member is generally accepted as the base of the Cretaceous although recent work questions some assumptions ${ }^{3-5}$. For the calculations here the Cinder Bed faunicycle ${ }^{2}$ is taken as representing the base of the Cretaceous.

If the Lulworth Beds are accepted as representing two ammonite zones, Table 1 shows values for the average length of a faunicycle (based on 20 faunicycles). The assignation of two ammonite zones to the Lulworth Beds may prove to be inaccurate and lead to re-interpretation of the values shown (for example, one ammonite zone for 20 faunicycles would give averages approaching the obliquity figure; M. R. House, personal communication). Anderson and Bazley ${ }^{2}$ considered that if the faunicycles were climatically induced, the precession of the equinoxes might have been responsible.

Sedimentary microrhythms can be recognized in the Lulworth Beds, and evidence of possible annual seasonal rhythmites can be seen in the deposits of restricted pools (Lower Dirt Bed of central Dorset) and also expressed in the pattern of fossil tree-growth rings ${ }^{6}$. There is much sedimentary variation in the Purbeck Beds due to their deposition marginal to a lagoon of fluctuating water level'

The faunal cyclicity of the Purbeck Beds reflects palaeoecological cyclicity that is

Table 1 Average length of a faunicycle

\begin{tabular}{ccc}
$\begin{array}{c}\text { Duration } \\
\text { of Jurassic } \\
\text { (Myr) }\end{array}$ & $\begin{array}{c}\text { Duration } \\
\text { of each zone } \\
\text { (Myr) }\end{array}$ & $\begin{array}{c}\text { Average } \\
\text { faunicycle } \\
\text { length } \\
(\mathrm{kyr})\end{array}$ \\
60 & 1.00 & 100 \\
65 & 1.08 & 108 \\
70 & 1.17 & 117 \\
75 & 1.25 & 125 \\
\hline
\end{tabular}

not mirrored by lithological microrhythms. Is it coincidence that this cyclicity averages $117 \mathrm{kyr}$, assuming the Jurassic to be $70 \mathrm{Myr}$ in duration? Is this an expression of the $100-\mathrm{kyr}$ cycle due to orbital forcing ${ }^{8}$ ? Ostracod assemblages have allowed correlation across northwest Europe in the late Jurassic and early Cretaceous, consisting of groups of ostracod zones and faunicycles. The faunicycles are assemblages of ostracod species; not purely evolutionary sequences, they represent changes in palaeoenvironment and may be laterally variable in their specific content ${ }^{2}$. The fact that the faunicycles persist over rapid lateral and vertical lithological/environmental changes suggests the involvement of some longer-term factors in the cyclicity. Might it be the case that, in palaeoenvironmental settings where sedimentary microrhythms are not manifestly obvious, such as in the marginal-marine Lulworth Beds of Dorset, biotic rhythmicity (ostracod faunicycles) reflects climatic cyclicity due to orbital forcing?

Note added in proof: Anderson ${ }^{10}$ has recognized one more faunicycle in the Purbeck Beds. Following assumptions made above the average faunicycle length is $111 \mathrm{kyr}$.

\section{Department of Geology and Mineralogy, \\ Marischal College, \\ Aberdeen University, \\ Aberdeen AB9 1AS, UK \\ 1. House, M. R. Nature 315, 721-725 (1985). \\ 2. Anderson, F. W. Bazley, R. A. B. Bull. geol Surv. Gt Brit. 34 (1971). \\ 3. Wimbledon, W. A. \& Hunt, C. O. Geol. Mag. 120(3), 267-280 (1983) \\ 4. Worssam, B. C. I Ivimey-Cook, H. C. Geol. Mag. 121(6), 651-652 (1984) \\ S. Norris, G. Geol Mag. 122(2), 187-190 (1985). \\ 6. Francis, J. E. Palaeogeogr. Palaeoclimatol, Palaeoecol. 48, 285-307 (1984) \\ 7. El-Shahat, A. \& West, I. Sediment. Geol 35, 15-41 (1983). \\ 8. Pisias, N. G. \& Shackleton, N. J. Nature 310, 757-759 (1984). \\ 9. Anderson, F. W. The Boreal Lower Cretaceous (eds Casey, R. \& Rawson, P. F.) 101-110 (Seel House Press, Liverpoot, 1973). \\ 10. Anderson, F. W. J. Micropalaeontod 4, 1-68 (1985)}

\section{Pre-Rhaetic therian mammals}

THE discovery of a Kuehneotherium tooth in deposits older than the Rhaetic transgression in Somerset, UK, was reported by Fraser, Walkden and Stewart ${ }^{1}$, who claim that it is the oldest record of a therian mammal, predating the kuehneotheriids from the supposedly 'Rhaetian' locality of Saint-Nicolas-de-Port in eastern France, described by Sigogneau-Russell ${ }^{2}$. However, one of us has recently studied the amphibian and reptile remains collected at Saint-Nicolas-de-Port by G. Wouters and P. Coupatez, and has compared this faunal assemblage with those from better known German localities ${ }^{3}$. This reveals that the Saint-Nicolas-de-Port fauna is of roughly the same age as that from Kuhn's levels $15-20$ of the Halberstadt locality ${ }^{4}$, and should thus be referred to the Norian.
Therefore, the Emborough Kuehnea therium and the mammals from SaintNicolas-de-Port may actually be of the same age, and may all qualify as the oldest known mammals.

The case of the Saint-Nicolas-de-Port locality illustrates the fact that the Rhaetian stage is of very doubtful value as far as continental faunas are concerned. The Rhaetian was first defined as the top of the marine Triassic in the northern Alps, but even there its validity has been questioned, as its fauna is not significantly different from that of the Norian, so that many stratigraphers have abandoned it altogether ${ }^{5}$. Outside the Alpine domain, the term Rhaetian is even less meaningful, especially in the Germanic domain where correlations are difficult. It seems to be impossible to define a typically Rhaetian vertebrate fauna, and vertebrate localities lumped together in the so-called Rhaetian may be of very different ages. We are therefore in full agreement with the opinion expressed by Fraser, Walkden and Stewart that the Emborough find "throws doubt on the fundamental distinctiveness of pre-Rhaetic and post-Rhaetic vertebrate faunas". Continued use of the terms Rhaetian and Rhaetic in a stratigraphical sense causes more problems than it solves, and cannot contribute to a better understanding of the relative stratigraphical position of late Triassic continental vertebrate localities.

ERIC BUFFETAUT
MICHEL MARTIN
Laboratoire de Paléontologie
des Vertébrés,
CNRS UA 720,
Université Paris VI,
4 place Jussieu,
75230 Paris Cedex 05,
France
1. Fraser, N. C., Walkden, G. M. \& Stewart, V. Nature 314,
161-163 (1985).
2. Sigogneau-Russell, D. Acta palaeont. pol. 28, 233-249
(1983); Zool, J. Linn. Soc. 78, 175-186 (1983).
3. Buffetaut, E. Terra cognita 5, 2-3, 133 (1985).
4. Kuhn, O. Paläont. Z. 21, 258-286 (1939).
5. Tozer, E. T. Geod. Surv. Canada Misc. Rep. 35, 1-171 (1984).

FRASER, Walkden and Stewart' have recently announced the discovery of fossil mammal teeth in a terrestrial fissure deposit at Emborough in the Mendip Hills (Somerset, UK). It has been dated by them as 'pre-Rhaetic' following Robinson ${ }^{2}$ who, in the then absence of direct palaeontological dating, invoked comparisons based on rock types, topographical position and the general nature of the faunal assemblage. We disagree with this.

Robinson's use of rock types for dating is inappropriate, since fissure fills and normal stratified sequence are of markedly different origin. The marl lithologies cited by Fraser et al.' as typical "pre-Rhaetic" are also known from the "Upper Rhaetic"3.

We envisage a situation where, in the prolonged period of sub-aerial exposure before, or during, the early Rhaetian, tectonic and solution features formed which 